\title{
Pengembangan Media Animasi PTG Berbantuan Adobe Animate CC Materi Satuan Panjang Kelas IV SDN 2 Cintaraja
}

\author{
Fatwa Fidia Nabilah \\ Universitas Muhammadiyah Tasikmalaya \\ fatwabella06@gmail.com

\section{Budi Hendrawan} \\ Universitas Muhammadiyah Tasikmalaya \\ hendrawan_budy@umtas.ac.id
}

\section{Mohammad Fahmi Nugraha}

Universitas Muhammadiyah Tasikmalaya m.fahminugraha@umtas.ac.id

\begin{abstract}
The research objective is to develop and test the effectiveness of the Adobe Animate CC hanging ladder tree animation instructional media towards the length relationship of the fourth grade students of SDN 2 Cintaraja. Type of research $(R \& D)$ and Sugiyono's adaptation development research model. There are 3 stages followed by data analysis and product revision. The data collection instruments were curriculum analysis, material analysis and similar media analysis. Data collection techniques using qualitative and quantitative data. The development data analysis technique used questionnaires and questions, namely the pretest and posttest. The results of the test scores were calculated using the Paired Sample T-Test analysis technique, the results obtained were $t>t$ or 19.733> 2.079 meaning that Ho was rejected and Ha was accepted, meaning that there was a significant difference between before and after using the media. The posttest average score was 84.04 above the value (KKM), namely 75.00. The posttest score of 84.04 is greater than the pretest value of 51.66 so that the learning media is said to be feasible and effective to use.
\end{abstract}

Keywords: $R \& D$ (Research and Development), Adobe Animate CC and Relationship Between Long Units.

\section{Pendahuluan}

Matematika adalah salah satu mata pelajaran yang pelajari pada satuan pendidikan dari berbagai jenang mulai dari TK, SD, SMP, SMA sampai Perguruan Tinggi, Matematika memiliki fungsi yang sangat penting dalam kehidupan sehari-hari, membantu manusia dalam menyelesaikan berbagai macam persoalan untuk memenuhi kebutuhan hidupnya. Hal ini sesuai dengan yang diungkapkan Turmudi (2008) bahwa matematika berkaitan erat dengan kehidupan sehari-hari sehingga dengan segera siswa akan mampu menerapkan matematika dalam konteks yang berguna bagi siswa, baik dalam dunia kehidupannya ataupun dalam dunia kerja. Dalam kenyataan yang terjadi, mempelajari matematika tidak serta mudah bagi keseluruhan peserta didik khususnya, akan tetapi harus memiliki motivasi dan semangat yang tinggi. karena pelajaran matematika sering dianggap sulit oleh 
setiap orang, namun setiap orang harus mempelajari Matematika untuk memecahkan masalah dalam kehidupan sehari-hari Marti (Sundayana, 2018).

Berdasarkan hasil wawancara tanggal 10 Desember 2019, pada pelajaran Matematika kelas IV di SDN 2 Cintaraja ditemukan bahwa terdapat beberapa hambatan dalam proses pembelajaran khususnya pada pelajaran Matematika materi hubungan antar satuan panjang. Dalam materi hubungan antar satuan panjang kesulitan peserta didik terletak pada menghafal satuan. Karena saat pembelajaran di kelas, selain peserta didik diminta untuk menghafal satuan panjang, peserta didik juga diterangkan materi oleh guru menggunakan cara konvensional yaitu dengan melukis tangga satuan panjang pada papan tulis. Menurut Hadi (2017) setiap masing-masing individu memiliki karakteristik kemampuan yang berbeda-beda. Ada yang berkemampuan cepat, sedang dan ada yang berkemampuan rendah.

Materi hubungan antar satuan panjang ini terdapat pada semester 2 dan terdapat di KD 3.7 dan 4.7. Jumlah peserta didik kelas IV di SDN 2 Cintaraja ada 21 orang siswa. Materi hubungan antar satuan panjang terdapat di semester 2 maka nilai untuk materi hubungan antar satuan panjang didapatkan dari siswa yang sekarang berada di kelas IV SDN 2 Cintaraja diperoleh nilai rata-rata keseluruhan siswa dari 34 orang siswa mencapai 74,01. Fakta yang ditemukan menunjukkan bahwa nilai rata-rata Matematika peserta didik untuk materi hubungan antar satuan panjang masih dibawah rata-rata nilai "Kriteria Ketuntasan Minimum (KKM)" yang ditetapkan oleh sekolah sebesar 75,00.

Berdasarkan hasil wawancara, teknik yang digunakan guru saat proses pembelajaran yaitu teknik diskusi dan langsung ke contoh soal saja. Pelajaran Matematika, materi hubungan antar satuan panjang dalam berhitung sangat membutuhkan ketepatan dan kehati-hatian. Siswa harus bisa mengalikan dan membagikan sepuluh dari setiap anak tangga yang akan di lewati, namun yang terjadi peserta didik terkadang lupa apabila menghadapi operasi hitung perkalian dan pembagian, belum lagi jika ada soal bilangan berkoma.

Dalam kegiatan belajar mengajar ditemukan guru di SDN 2 Cintaraja belum menggunakan media pembelajaran sebagai "senjata" dalam kegiatan pembelajaran terkhusus pada materi hubungan antar satuan panjang dan lebih banyak menjelaskan materi kemudian siswa langsung diminta untuk mengerjakan soal, akibatnya peserta didik kurang memahami materi tersebut. Seharusnya guru harus menyadari bahwa peran media pembelajaran memberikan dampak yang positif.

Jadi, diperlukan inovasi pengembangan media pembelajaran khususnya untuk materi hubungan antar satuan panjang. Dari hasil wawancara yang dilakukan di kelas IV SDN 2 Cintaraja yaitu belum ada media khusus untuk materi hubungan antar satuan panjang. Maka dengan dasar inilah dibuat media pembelajaran animasi Pohon Tangga Gantung (PTG) berbantuan adobe animate cc. Alasan memilih media ini, karena media ini cocok dengan karakteristik peserta didik yang memerlukan sesuatu yang konkret untuk memudahkan penyampaian materi hubungan antar satuan panjang agar dapat tersampaikan dengan mudah dan menarik.

Menurut guru atau wali kelas, kelas IV SDN 2 Cintaraja, dalam menghitung hubungan antar satuan panjang hanya menggambar tangga di papan tulis dan itu beda halnya dengan media pembelajaran animasi PTG berbantuan adobe animate cc. 
Media ini di desain menggunakan animasi yang di dalam animasi tersebut bentuk medianya seperti pohon dan di batang pohon terdapat tangga, yang mana setiap tangga diberi tulisan $\mathrm{km}, \mathrm{hm}$, dam, $\mathrm{m}$, dm, $\mathrm{cm}$, dan $\mathrm{mm}$. Selain itu media ini juga dilengkapi dengan media operasi hitung papan gantung untuk mempermudah bagaimana cara menghitungnya. Media pembelajaran animasi PTG berbantuan adobe animate $c c$ ini diharapkan dapat mempermudah siswa dalam memahami materi yang disampaikan oleh guru. Tujuan dari riset ini adalah untuk mengembangkan dan menguji efektivitas media pembelajaran animasi PTG berbantuan adobe animate $c c$ pada materi hubungan antar satuan panjang untuk siswa kelas IV SDN 2 Cintaraja. Berdasarkan penjelasan di atas peneliti akan melakukan penelitian dengan judul "Pengembangan Media Pembelajaran Animasi PTG Berbantuan Adobe Animate CC Pada Materi Hubungan Antar Satuan Panjang Kelas IV di SDN 2 Cintaraja.

\section{Metode}

Bentuk riset ini termasuk ke dalam bentuk dan desain penelitian pengembangan atau Research and Development (R\&D). Menurut Sugiyono (2019) metode penelitian dan pengembangan Research and Development (R\&D) yaitu melakukan penelitian, melakukan perancangan, melakukan tahap produksi dan selanjutnya melakukan tahap pengujian. Dalam riset ini menggunakan bentuk penelitian pengembangan adaptasi dari Sugiyono. Langkah-langkah model penelitian pengembangan adaptasi dari Sugiyono yaitu potensi dan masalah, pengumpulan data, desain produk, validasi desain, revisi desain, uji coba produk, revisi produk dan jadilah produk media pembelajaran animasi pohon tangga gantung berbantuan adobe animate cc.

Partisipan dalam riset pengembangan ini yaitu peserta didik kelas IV sebanyak 21 orang peserta didik yang dilakukan untuk tahap uji coba kelompok besar. Selanjutnya, sebanyak 3 orang peserta didik yang dilakukan untuk tahap uji coba satu-satu dan sebanyak 10 orang peserta didik yang dilakukan untuk tahap uji coba kelompok kecil.

Instrumen pengumpulan data dengan cara mengumpulkan berbagai informasi dari analisis kurikulum, analisis materi dan analisis media sejenis. Setelah mengetahui kurikulum yang berlaku di sekolah maka dapat diketahui kompetensi dasar yang akan dicapai pada pelajaran Matematika materi hubungan antar satuan panjang. Kemudian analisis materi yaitu mengidentifikasi materi Matematika di kelas IV SD, lalu identifikasi materi Matematika apa saja yang terdapat permasalahan yang lebih menonjol yang nantinya akan ditampilkan pada media pembelajaran. Jadi, untuk mengatasi masalah pada pembelajaran materi hubungan antar satuan panjang, peneliti juga melakukan analisis media sejenis.

Teknik pengumpulan data yang diperoleh dalam riset ini menggunakan data kualitatif dan data kuantitatif. Data kualitatif diperoleh dari hasil validasi angket yang berupa saran. Data kuantitatif diperoleh dari skor tanggapan para ahli, guru dan siswa untuk mengukur kelayakan media, serta skor pretest dan posttest untuk mengetahui keefektifan media.

Teknik analisis data pada penelitian ini adalah menggunakan analisis data pengembangan adaptasi dari Sugiyono (2019) yaitu:

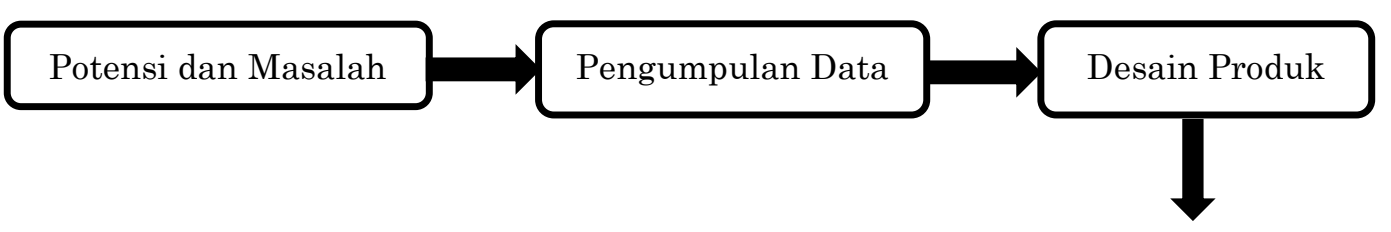




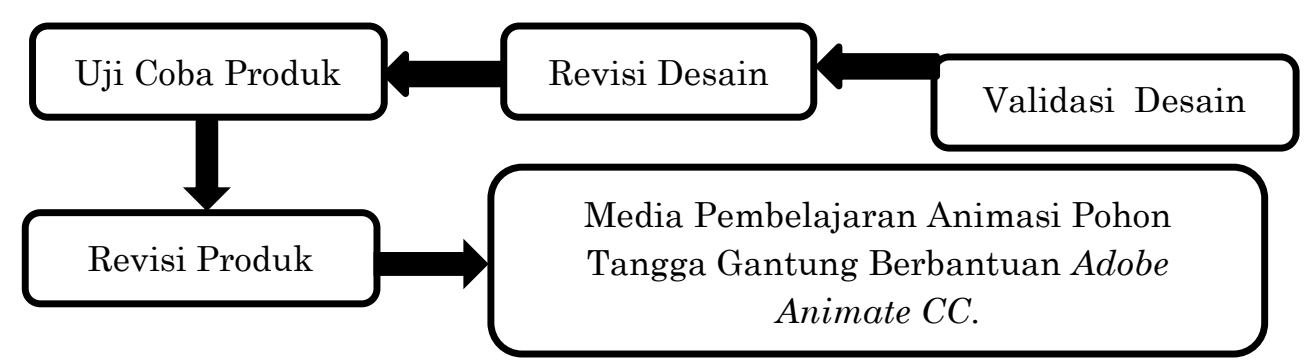

Gambar 1. Teknik Analisis Data Penelitian R\&D Adaptasi Sugiyono

\section{Hasil}

Media pembelajaran pohon tangga gantung merupakan media pembelajaran yang dapat digunakan untuk membantu guru dalam menyampaikan materi hubungan antar satuan panjang pada pelajaran Matematika. Media pembelajaran pohon tangga gantung adalah media yang diadopsi dari tangga untuk berhitung mengenai hubungan antar satuan panjang. Pada media pembelajaran ini terdapat menu tujuan pembelajaran yang di dalamnya terdapat menu kompetensi dasar, indikator dan referensi. Selain itu juga terdapat menu petunjuk yang di dalamnya terdapat menu fungsi tombol dan fungsi menu media pohon tangga gantung. Media pembelajaran pohon tangga gantung jika dilihat dari sifatnya termasuk ke dalam media audio visual berbantuan adobe animate $c c$ karena media pembelajaran ini dibuat aplikasi yang di dalamnya terdapat menu pembelajaran yang berisikan menu materi 1 , materi 2 , materi 3 , contoh pembelajaran media pohon tangga gantung dan permainan media pohon tangga gantung yang di dalamnya juga terdapat suara pemandu. Menu selanjutnya yaitu ada menu latihan dan quiz yang berisikan soalsoal materi hubungan antar satuan panjang yang dapat membantu siswa untuk siswa belajar dalam mengerjakan soal.

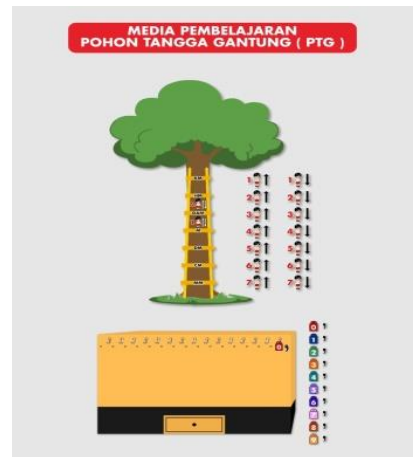

Gambar 2. Gambar Media Pembelajaran Pohon Tangga Gantung

Setelah dilakukan uji validitas isi dan validitas konstruk maka soal pretest dan posttest akan valid dan reliable. Selanjutnya siswa diberikan soal pretest yang bertujuan untuk mengukur kemampuan awal siswa pada materi hubungan antar satuan panjang dan soal posttest yang bertujuan untuk mengukur kemampuan siswa setelah diberikan tindakan menggunakan media pembelajaran pembelajaran animasi pohon tangga gantung berbantuan adobe animate $c c$. Uji coba produk dilakukan 3 tahap.

Uji coba satu-satu yang dilakukan kepada 3 orang peserta didik yang dilanjutkan dengan analisis data dan revisi produk. Siswa diberikan pembelajaran dan praktek menggunakan media pembelajaran animasi pohon tangga gantung berbantuan adobe 
animate $c c$, lalu peserta didik diberikan angket untuk menanggapi dan menilai pembelajaran ketika siswa menggunakan media pembelajaran animasi pohon tangga gantung berbantuan adobe animate cc. Setelah data terkumpul melalui angket, selanjutnya dilakukan analisis dengan konversi data kualitatif ke kuantitatif dengan menggunakan skala lima dan perolehan skor angket dihitung dengan cara mencari rata-rata yaitu menggunakan rumus Widoyoko. Hasil dari analisis data uji coba satu-satu, keseluruhan skor rata-rata yaitu 4,88 dengan kategori "Sangat Baik" dan tidak terdapat saran/masukan sebagai bahan untuk revisi atau perbaikan.

Uji coba kelompok kecil yang dilakukan kepada 10 orang peserta didik yang dilanjutkan dengan analisis data dan revisi produk. Peserta didik diberikan pembelajaran dan praktek menggunakan media pembelajaran animasi pohon tangga gantung berbantuan adobe animate cc, lalu peserta didik diberikan angket untuk menanggapi dan menilai pembelajaran ketika siswa menggunakan media pembelajaran animasi pohon tangga gantung berbantuan adobe animate cc. Setelah data terkumpul melalui angket, selanjutnya dilakukan analisis dengan konversi data kualitatif ke kuantitatif dengan menggunakan skala lima dan perolehan skor angket dihitung dengan cara mencari rata-rata yaitu menggunakan rumus Widoyoko. Hasil dari analisis data uji coba kelompok kecil, keseluruhan skor rata-rata yaitu 4,78 dengan kategori "Sangat Baik" dan tidak terdapat saran/masukan sebagai bahan untuk revisi atau perbaikan.

Uji coba kelompok besar yaitu uji coba yang dilakukan kepada 21 orang peserta didik. Pada tahap uji coba kelompok besar, peserta didik diberika tindakan sebanyak 3 kali pertemuan. Hasil data nilai rata-rata pretest 51,66 dan rata-rata posttest 84,04. Hal ini menunjukkan bahwa nilai posttest lebih tinggi daripada nilai pretest. Nilai kualitas tingkat keefektifan media secara keseluruhan yaitu 0,67 dengan kategori "Sedang".

Selanjutnya, sebelum dilakukan penghitungan analisis uji kefektifan menggunakan Uji N-Gain dan uji hipotesis dengan menggunakan Paired Sampel T-Test maka terlebih dahulu harus dilakukan uji normalitas data dengan menggunakan uji Shapiro-Wilk.

Hasil uji normalitas nilai Sig. (2-tailed) pada pretest $0,062>0,05$ dan pada posttest $0,158>0,05$. Artinya hasil data yang digunakan dalam penelitian ini telah berdistribusi normal. apabila sudah berdistribusi normal maka dapat dilakukan analisis uji keefektifan dengan menggunakan Uji $N$ - Gain dan Paired Sampel TTest. Uji $N$ - Gain atau nilai kualitas tingkat keefektifan media secara keseluruhan yaitu 0,67 dengan kategori Sedang. Selanjutnya analisis dengan Uji Paired Sampel T-Test dengan taraf signifikan 0,05.

Hasil Uji Paired Sampel T-Test menunjukkan hitung $_{19}$ 19,733 dengan df 20, sehingga t tabel 2,079 dengan taraf signifikan 0,05 maka $\mathrm{t}_{\text {hitung }}>\mathrm{t}_{\text {tabel }}$ atau 19,733 $>2,079$. Dengan demikian, jadi Ho ditolak dan Ha diterima artinya terdapat perbedaan signifikan antara sebelum dan sesudah diberikan perlakuan menggunakan media pembelajaran pohon tangga gantung berbantuan adobe animate $c c$ pada materi hubungan antar satuan panjang di SDN 2 Cintaraja. Hasil rata-rata posttest 84,04 dan sudah berada di atas nilai Kriteria Kelulusan Minimal (KKM) yaitu 75,00. Berdasarkan hasil rata-rata, nilai posttest 84,04 lebih besar dari pada nilai pretest 51,66, maka media pembelajaran pohon tangga gantung berbantuan adobe animate $c c$ dapat dikatakan layak dan efektif untuk digunakan pada pelajaran Matematika materi hubungan antar satuan panjang. 
Berdasarkan uraian di atas, maka dapat disimpulkan bahwa media pembelajaran pohon tangga gantung berbantuan adobe animate $c c$ dapat dikatakan layak dan efektif untuk digunakan pada pelajaran Matematika materi hubungan antar satuan.

\section{Pembahasan}

Media sangat penting dalam proses pembelajaran. Hal ini selaras dengan hasil penelitian yang dilakukan Mukhlisoh (2017) yang mana menurutnya kemenarikan media pembelajaran merupakan sebagai pendukung dalam menjelaskan materi pembelajaran pada Matematika. Media pembelajaran yang menyenangkan dan menarik akan lebih mudah dipahami oleh siswa dalam proses pembelajaran.

Menurut Criticos dalam Daryanto (2016) media merupakan salah satu komponen komunikasi yaitu sebagai pembawa pesan dari komunikator menuju komunikan. Berdasarkan definisi tersebut, dapat dikatakan bahwa proses pembelajaran merupakan proses komunikasi.

Menurut Kemp dan Dayton dalam Sundayana (2018) ada beberapa manfaat media pembelajaran dalam proses pembelajaran yaitu antara lain: penyampaian materi dapat diseragamkan, proses pembelajaran menjadi lebih jelas dan menarik, proses pembelajaran lebih interaktif, efisiensi dalam waktu dan tenaga, meningkatkan kualitas hasil belajar siswa, media memungkinkan proses belajar dapat dilakukan di mana saja dan kapan saja, media dapat menumbuhkan setiap siswa terhadap materi dan proses belajar dan dapat menambah peran guru menjadi lebih positif dan produktif.

Menurut Sanjaya dalam Sundayana (2018) media pembelajaran dapat diklasifikasikan menjadi beberapa jenis tergantung dari sudut mana melihatnya yaitu jika dilihat dari sifatnya media pembelajaran dapat dibagi menjadi media auditif, media visual dan media audiovisual. Jika dilihat dari kemampuan jangkauannya, media dapat pula dibagi menjadi media yang memiliki daya liput yang luas dan serentak, serta media yang mempunyai daya liput yang terbatas oleh ruang dan waktu. Selanjutnya jika dilihat dari cara atau teknik pemakaiannya, media dapat dibagi menjadi media yang diproyeksikan dan media yang tidak diproyeksikan.

Menurut Sudirman dalam Sundayana (2018) mengemukakan beberapa prinsip pemilihan media pembelajaran yang dibaginya ke dalam tiga kategori yaitu tujuan pemilihan, alternatif pemilihan dan kriteria pemilihan media pembelajaran. Gerlach dan Erly dalam Sundayana (2018) mengemukakan tiga ciri media pembelajaran yaitu ciri fiksatif, ciri manipulatif dan ciri distributif.

Menurut Wibowo dalam Sundayana (2018) masalah yang sering ditemui di lapangan/di sekolah, mengapa sampai saat ini masih ada guru yang enggan menggunakan media pembelajaran dalam mengajar yaitu menggunakan media pembelajaran itu repot, media itu canggih dan mahal, tidak bisa menggunakan media pembelajaran yang berbasis teknologi, media itu hiburan (membuat siswa main-main dan tidak serius), sedangkan belajar itu serius, tidak tersedia media pembelajaran di sekolah, kebiasaan menikmati ceramah atau bicara dan kurangnya penghargaan dari atasan.

Media pembelajaran ini digunakan untuk memahami materi hubungan antar satuan panjang. Menurut Mukhlis (2017) mengukur merupakan kegiatan penting dalam 
kehidupan untuk membandingkan suatu besaran yang diukur dengan besaran sejenis yang dipakai sebagai satuan. Menurut Cato (2019) pengukuran satuan panjang adalah memberikan informasi mengenai seberapa panjang suatu benda. Menurut Nurhasanah (2019) pengukuran satuan panjang dapat dibagi menjadi dua yaitu satuan tidak baku dan satuan baku.

Menurut Piaget dalam Ibda (2015) perkembangan kognitif merupakan pertumbuhan berpikir logis dari masa bayi hingga dewasa yang berlangsung melalui tahap sensorimotor (0-1,5 tahun), tahap pra-opersional (1,5-6 tahun), tahap operasional konkret (6-12 tahun) dan tahap operasional formal (12 tahun ke atas). Jadi media ini disesuaikan dengan karakteristik siswa kelas IV SD yaitu tahap operasional konkret yang mana anak sudah cukup matang untuk menggunakan pemikiran logika atau operasi, tetapi hanya untuk objek fisik yang ada saat ini.

Media pembelajaran ini juga dirancang menggunakan berbantuan adobe animate cc. Menurut Ahmadi (2018) adobe animate cc (creative cloud) merupakan pengembangan dari adobe flash professional, macromedia flash dan future splash.

\section{Simpulan}

Simpulan dari penelitian ini adalah pengembangan media pembelajaran pohon tangga gantung berbantuan adobe animate $c c$ dalam tahap pengembangannya, terlebih dahulu melihat potensi masalah, selanjutnya melakukan pengumpulan data. Kemudian membuat rancangan media pembelajaran pada story board, flowchart view dan cara penggunaan media pembelajaran yang dituangkan ke dalam software adobe animate $c c$ hingga menjadi media pembelajaran pohon tangga gantung berbantuan adobe animate cc. Tahap selanjutnya yaitu melakukan validasi desain. Hasil yang didapatkan dari validasi ahli materi yaitu sebesar 4,88 dengan kategori "Sangat Baik", hasil validasi ahli media yaitu sebesar 4,92 dengan kategori "Sangat Baik" dan hasil validasi guru yaitu sebesar 4,94 dengan kategori "Sangat Baik", sehingga media pembelajaran pohon tangga gantung berbantuan adobe animate $c c$ ini sudah valid dan layak untuk diuji cobakan. Tahap selanjutnya yaitu revisi desain, total revisi sebanyak 4 kali dari keseluruhan validator. Tahap selanjutnya yaitu melakukan uji coba coba produk yang dilakukan sebanyak 3 kali yaitu uji coba satu-satu yang dilakukan kepada 3 orang siswa dan diperoleh dengan hasil rata-rata yaitu sebesar 4,88 dengan kategori "Sangat Baik", uji coba kelompok kecil yang dilakukan kepada 10 orang siswa dan diperoleh hasil rata-rata yaitu sebesar 4,78 dengan kategori "Sangat Baik" dan uji coba kelompok besar yang dilakukan kepada 21 orang siswa dan diperoleh hasil dengan melihat hasil rata-rata nilai pretest yaitu sebesar 51,66 dan nilai posttest yaitu sebesar 84,04 .

Berdasarkan hasil uji normalitas bahwa nilai Sig. (2-tailed) pada pretest yaitu sebesar 0,062 >0,05 dan pada posttest sebesar 0,158>0,05. Artinya hasil tersebut dapat dinyatakan bahwa data yang digunakan dalam penelitian ini telah berdistribusi normal. Media pembelajaran pohon tangga gantung berbantuan adobe animate $c c$ efektif digunakan pada materi hubungan antar satuan panjang di SDN 2 Cintaraja. Hasil nilai pretest dan nilai posttest dihitung dengan menggunakan teknik analisis Paired Sampel T-Test dengan diperoleh hasil $\mathrm{t}_{\text {hitung }}>\mathrm{t}_{\text {tabel }}$ atau 19,733 > 2,079 yang artinya Ho ditolak dan Ha diterima artinya terdapat perbedaan signifikan antara sebelum dan sesudah diberikan perlakuan menggunakan media pembelajaran pohon tangga gantung berbantuan adobe animate $c c$ pada materi hubungan antar satuan panjang di SDN 2 Cintaraja. Selain itu, dilihat dari hasil rata-rata nilai posttest siswa yaitu sebesar 84,04 dan sudah berada di atas nilai Kriteria Kelulusan Minimal (KKM) pada mata pelajaran Matematika yaitu sebesar 
75,00. Berdasarkan hasil rata-rata, maka yaitu nilai posttest 84,04 lebih besar dari pada nilai pretest 51,66, maka media pembelajaran pohon tangga gantung berbantuan adobe animate $c c$ dapat dikatakan layak dan efektif untuk digunakan pada pelajaran Matematika materi hubungan antar satuan panjang.

\section{Saran}

Berdasarkan hasil riset dan pengembangan media pembelajaran pohon tangga gantung berbantuan adobe animate $c c$ ini, terdapat beberapa saran yaitu:

1. Media pembelajaran pohon tangga gantung berbantuan adobe animate $c c$ ini diharapkan dapat mempermudah siswa dalam memahami materi hubungan antar satuan panjang pada pelajaran Matematika.

2. Media pembelajaran pohon tangga gantung berbantuan adobe animate cc ini diharapkan dapat dijadikan alat bantu dalam pembelajaran bagi siswa kelas IV di Sekolah Dasar secara klasikal maupun privat.

3. Media pembelajaran pohon tangga gantung berbantuan adobe animate $c c$ ini dirancang dengan berbasis IT (information technology), maka agar mencapai hasil yang lebih maksimal, seharusnya sekolah dapat menyediakan laboratorium komputer dan orang tua juga dapat menyediakan laptop/komputer untuk anaknya agar setiap siswa atau anak dapat mencoba dan berlatih soal menggunakan media pembelajaran secara langsung pada laptop/komputer.

4. Masih perlu adanya pengembangan lebih lanjut pada media pembelajaran pohon tangga gantung berbantuan adobe animate cc yang lebih menarik lagi dengan cakupan yang lebih luas.

\section{Referensi}

Ahmadi, A., K. 2018. Pengembangan Adobe Animate CC Sebagai Media Pembelajaran Geografi Untuk Meningkatkan Hasil Belajar Siswa Kelas IX IPS 1 MAN 1 Lamongan. Malang: Universitas Islam Negeri Maulana Malik Ibrahim Malang.

Cato, S. 2019. Problem Matematika Pengukuran. Bandung: Pakar Raya.

Daryanto. 2016. Media Pembelajaran (Ed. Rev). Yogyakarta: Gava Media.

Ibda, F. 2015. Perkembangan Kognitif Teori Jean Piaget. Intelektualita, 3(1), 27-38.

Mukhlis. 2017. Pembelajaran Model Inquiri Terbimbing Pada Materi Besaran Dan Satuan Untuk Meningkatkan Keterampilan Generik Sains dan Hasil Belajar Mahasiswa. Lantanida Journal. 5(1), 29-41.

Mukhlisoh, U. 2017. Pengembangan Media Pembelajaran Satuan Panjang Satuan Berat Berbasis Strategi Mnemonic di Kelas IV Sekolah Dasar. Jambi: Universitas Jambi.

Nurhasanah, L. 2019. Seri Matematika Untuk Anak Mengenal Pengukuran. Bandung: PT Graha Bandung Kencana.

Sugiyono. 2019. Metode Penelitian dan Pengembangan (Research and Development/ $R \& D)$. Bandung: Alfabeta.

Sundayana, Ro. 2018. Media dan Alat Peraga dalam Pembelajaran Matematika. Bandung: Alfabeta.

Turmudi. 2008. Taktik dan Strategi pembelajaran matematika (berparadigma eksploratif dan investigatif). Jakarta : Leuser cipta pustaka. 